\title{
From Mystery to Initiation: A Mytho-Ritual Poetics of Love and Sex in the Ancient Novel - even in Apuleius' Golden Ass?
}

\begin{abstract}
As far as myth and ritual are concerned, we have only recently witnessed a hermeneutical shift from R. Merkelbach's allegorizing view of the novel as a mystery text to the paradigm of initiation where young people experience the rite of passage to adulthood. On the basis of a new bio-ritual, psycho-anthropological model, it will be argued that the ancient novels, which are built on traditional wondertales, focus upon, rework, revolve around and help to overcome the central crisis of puberty, very often from the vantage point of the girl.

The change of focus will be explored through Apuleius' Golden Ass, a rather atypical novel that, due to Lucius' initiation into the secret rites of Isis in Book 11, has served as the model for mystery interpretation until now. However, despite all the differences from the ideal romances, Apuleius, too, deals with the crucial threshold of adolescence. It will be shown that Lucius, the young protagonist, acts out his male obsessions with love and sexuality, while the narration is similar to a dream sequence on the level of a fairy-tale folk structure. Furthermore, the 'girl's tragedy' coming of age is also debated through the medium of the ass: within the texture of the narrative the sexual nightmare is particularly highlighted in Charite's drama, which is again refracted in the inlay tale of Cupid and Psyche.
\end{abstract}

\section{Theoretical Introduction to Myth and Ritual in the Novel}

Religion, myth and ritual are ubiquitous features of the novel. Everywhere, we meet reflections of ancient myths, cults and mysteries. Reading the novels, we come across theological syncretism, epiphanies and integrations of the traditional and the new, foreign gods, superstition, magic, oracles and visions. ${ }^{1}$ The meaning of these discourses depends on the modern definitions which we apply.

1 See Bierl 2007 and Zeitlin 2008. For Apuleius, see Harrison 2007. 
Myth and ritual tend to be seen in a universalizing, totalizing and reductionist manner.

When considering religion in the novel, different readings tend to be applied. Either (1) the novel is used as a source for the history of religion, and a serious religious intention is postulated, a good example in this respect being Reinhold Merkelbach's allegorizing view of the novels as 'mystery texts' ${ }^{2}$ which provide literary entertainment only 'on the surface level', while their 'deeper meaning,3 would have been understood only by initiates. According to this approach, literature serves to convey an extra-literary content, ${ }^{4}$ and religion is thus the serious intention or message of the genre. ${ }^{5}$ Alternatively (2) these elements are interpreted as being only material within the imaginative plot. ${ }^{6}$

To some extent, I share the latter position. First of all, we have to recognize the interpenetration and interdependence of literature and religion. ${ }^{7}$ Myth and rituals serve, according to Stephen Greenblatt, as centers of 'circulation of social energy,', and become, according to Gerhard Neumann, 'generators of patterns of action and narration in poetic texts." As a megatext, they are part of a cultural machine which constantly brings forward new forms by variation and combination. Everybody refers to them, and all literary and aesthetic concretisations constantly debate, affirm, reshape and undermine these discourses.

In order to yield new insights, one has to realize that myth and ritual are modes of expression that mediate binary opposites. We have to build on more flexible models which include performance, reception, folktale and magical wondertale, cultural studies, biology and narration, as Margaret Alexiou (2002) refreshingly does. For my new eclectic and holistic approach to the ancient novel, I have learnt much from her.

Metaphors and metonymies are interrelated with ritual and myth and serve as their vehicle. ${ }^{10} \mathrm{~A}$ metaphor can generate a ritual by putting in motion other

2 Merkelbach 1962, esp. the Preface; 1988; 1995.

3 Merkelbach 1962, 90, 125 n. 2, 295, 298; 1995, 335-339, esp. 337-338; see also 1988, 4, 138-139.

4 See Merkelbach 1962; 1988; 1995. See also Kerényi 1927; for a mediating position, see Beck 1982, who identifies the mysterious with the quest for salvation. Reardon 1991, 169-180 suggests that socio-political, psychological and religious factors are responsible. For a typological and 'allegorical' modern-life mythology, see Dowden 2005.

5 For Apuleius, see e.g. Dowden 1998.

6 Winkler 1982; 1985.

7 Bierl 2007.

8 Greenblatt 1988, 1-20.

9 Neumann 2000, 19.

10 See Alexiou 2002, esp. 317-319. 
metaphors which are activated by similarity or contiguity. ${ }^{11}$ Metaphors and rituals refer to action. Due to their iconic qualities, metaphors understood literally can be transformed in action and narration. They are movers and shifters which trigger actions: 'Metaphor shapes ritual (conventional action), just as ritual gives body to metaphor.'12

Myths often have to do with dreams and resort to the fantastic, the uncanny and the miraculous. Myth and ritual generate the material of the ancient novel both the ideal Greek novel of love and adventure and the more parodic and satirical Latin novel. Both have to be associated with the imaginary and fantastic. ${ }^{13}$ And the dividing line between the ideal and the satirical novel is much more transparent than has been assumed. Even in ideal Greek novels, we find breaches of the norm, parodic and ironic twists, and comic perspectives. Myth and ritual also underlie the oral forms of folktale and popular stories. With the dominance of literacy, oral and performative elements of myth and ritual do not disappear, as one normally assumes, but are transformed and live on. In the novel they have the same functions of dealing with, playing with, affirming, undermining, deferring and transferring threatening elements in order to better cope with life. Myth and ritual therefore have many elements in common with novels which occur less frequently or typically in other forms of literature: violence, terror, miracles, contact with gods, heroes, the super- and supranatural, excess, excrements, corporeal fluids, food, sex, the foreign or the 'Other. ${ }^{14}$ By entering into this world of the 'Other' - and by 'emerging from it' - the novel shares with myth and ritual the structure of the rite de passage.

Only quite recently has there been a shift away from reading novels as mystery texts - in exaggerated allegorical readings à la Merkelbach, who has always met with considerable scepticism - to interpreting them in terms of the initiation of age groups. The underlying theme of a rite de passage seems to be so obvious that it is astonishing that it has only been associated with the novel within the last few years. ${ }^{15}$ One can, however, postulate a structural and perhaps even a genetic affinity between the two paradigms of religion and of a rite de passage. The tripartite pattern of action detected by Arnold van Gennep (separation, liminality, reintegration) forms the basis of almost all stories. ${ }^{16}$ Thus, there

11 See Fernandez 1977; 1986; 1991.

12 Alexiou 2002, 318, and, in general, 317-410.

13 See Alexiou 2002, 211-314.

14 Alexiou 2002, 317-348.

15 See now Lalanne 2006 and Bierl 2007. For the initiation structure of the novel, see Burkert 1987, 66-67; Whitmarsh 1999; Dowden 1999; 2005.

16 Gennep 1960. For Apul. Met., see Habinek 1990. 
is a certain danger that such a pattern might be used as a passe par tout. ${ }^{17}$ In the love novel, it is almost self-evident: boys and girls act in their years of puberty, and the goal - the telos - of their initiation story, is marriage. ${ }^{18}$ Both youths are introduced into adulthood through the celebration of wedlock. In the discourse of the love novel, we see a separation from the former condition of life, a transition, while travelling through the world of the 'Other', and then a return into society. However, even in this new ritual paradigm, we find again a tendency to project serious intentions onto the texts: the novel is read as a means of paideia, as a Bildungsroman. ${ }^{19}$ The first monograph to advance the initiation thesis, the recent work by Sophie Lalanne, understands the novel as a historical and socio-political source. According to her, these fictional texts served the Greek elites in Asia Minor by redefining their identity under the domain of Rome: they provided a medium for self-assertion and gender-modelling. ${ }^{20}$ From such a perspective, we are again in danger of forgetting the special status of literature, the alteritive character of the novel. Therefore, I want to focus on the literary, ritual and ironic aspects, as well as the playful and imaginary character of these texts based on puberty rites.

In what follows, I would like to introduce a new model for reading the ancient novel, using a ritual and mythical poetics linked to puberty initiation. I contend that both discourses - the religious modes of expression, and the novel, based on orally transmitted traditional wondertales - focus upon, rework, circulate around, retract and help to overcome the central crisis of marriage as well as of the discovery of sexuality. This is very often presented from the vantage point of the girl. Novels as well as popular Greek stories deal with these issues in a dreamlike manner in positive and negative ways. Fears, nightmares of monsters and scenarios of blood and sacrifice are mingled with euphoric phantasies. Love, thus, becomes decisive for the genre. Very young adolescents are the protagonists. The objective, or telos, of the fictions is marriage, but between the frame of a beginning and an ending, we find the young lovers during their phase of marginality in a loop of destabilizing thoughts and adventures in liminal spaces. ${ }^{21}$ This means that behind the novelistic plots and traditional tales, we see a 'biological track', a psycho-anthropological basis. ${ }^{22}$ We have to do with the 'maiden's tragedy', but less in the sense of Walter Burkert, who tries to establish a

17 See Versnel 1993, 51-74.

18 See also Bierl 2001, index s.v. 'Hochzeit'.

19 E.g. Morgan 1996; Lalanne 2006.

20 Lalanne 2006, 183-274.

21 Bierl 2007 (with a summary of the indicative themes and motifs of initiation, 265-276).

22 See Neumann 2007; 2010. 
structural program of action in these terms, ${ }^{23}$ than as a loose set of motifs which can be freely associated in various combinations. Love and the irritating sentiments connected with it are the motor of the genre. Erotic feelings, as disease and nosos, express desire. The sense of absence gives way to miraculous fantasies of loss, fear, sexual threats by third parties, death and rebirth; they are transformed into stories of separation, sacrifice, rape and violence. In a Lacanian sense, the quintessential absence, the deep longing, leads to a gliding concatenation of signifiers in a metaphorical and metonymical process. ${ }^{24}$ In modern Greek culture, such wondertales are called paramithia, stories that go in between, transform, transgress and, by telling, provide paramythía, relief, reassurance and consolation. $^{25}$

I would argue that for the ancient love novel, the erotic discourse as a texture of literature and narrative is constitutive and dominant. Love and sex set the parameters of the genre. ${ }^{26}$ The ritual poetics of the novel, where puberty initiation functions as a sort of master discourse, is based on love, since the adolescents become aware of the feeling of love, are affected by intense erotic bewilderment as if by disease and pathos, and have to find a means of coping with it. Marriage, as telos, is the happy ending: love has to be transformed into socially acceptable forms of cohabitation. The severe crisis of sudden puberty and the awakening of erotic feeling, of menstruation and potential pregnancy, is acted out as a pathological experience of the 'Betwixt and Between. ${ }^{27}$

\section{Apuleius' Golden Ass - an Atypical Novel?}

I have begun to analyze the main Greek novels in other places on the premises of such a new bio-ritual approach. ${ }^{28}$ An interesting test case is the Metamorphoses of Apuleius, an atypical representative of the genre, insofar as it is a non-ideal, Latin, and a rather satirical novel. In the standard love novel, the arousal of interest results in the act of falling in love, while in further novel-like textual productions, i.e. the so-called fringe novels, such a pothos can also be presented as curiosity, desire for knowledge, justice, piety, or mystery-like

23 Burkert 1996, 69-79 (on the model of Psyche in Apul. Met.).

24 Bierl 2006; 2007, 244-245.

25 Alexiou 2002, 151-171, esp. 162-167, 211-265; Bierl 2007, 255-258.

26 Bierl 2002; 2006; 2007.

27 Turner 1967, 93-111.

28 Bierl 2006; 2007. 
knowledge. ${ }^{29}$ Apuleius has partly worked within this tradition. Curiosity is a key issue in the plot construction of the Golden Ass. ${ }^{30}$ To advocate an interpretative paradigm shift from mystery to initiation is perhaps the more striking, since, due to Lucius' initiation into the mysteries of Isis in Book 11, the Metamorphoses has until now been the model par excellence for any serious religious interpretation of mystery initiation. Merkelbach took Apuleius as the starting point for his Roman und Mysterium, ${ }^{31}$ and many critics have considered the novel either as serious, religious propaganda or as a story of conversion. ${ }^{32}$ Jack Winkler (1985, esp. 204-247), however, shattered this reading and replaced it with a postmodern openness, while Stephen Harrison (2000, 210-259) pleads for an explicitly satirical interpretation of the last book as well. ${ }^{33}$ Nonetheless, the decisive question remains, how to link Book 11 with Books 1 to $10 .{ }^{34}$ In what follows, I will argue that the connection runs over clusters of images, over a web of metaphors and metonymies within the basic realm of love. ${ }^{35}$ In the ideal novels (the 'Big Five'), too, the themes of religion, philosophy, myth and mystery have been used to convey dignity and grandeur. ${ }^{36}$ In the vein of authors of the Second Sophistic, the novelists want to display their knowledge. The pepaideumenoi tend to elevate corporeal love and base sexual instinct to something sacred, to associate it with the initiation into mysteries, with alignment to and convergence with mythical beauties and ritual contexts. ${ }^{37}$

In many respects, the Golden Ass is an atypical novel. It does not begin with an experience of love at first sight, there is scarcely a couple, apart from Lucius and Photis - and even this love episode is more instrumental than central; there is no intense feeling between them, but only a physical relationship. The usual oath of mutual faithfulness is also missing. The long Apuleian text consists not only of one clear-cut plot, but also of many inserted tales. ${ }^{38}$ We are familiar with this feature through Xenophon or Longus, but in Apuleius, the entire story is

29 Compare the so-called fringe novels, the utopian travel narratives, the novel-like fictional biography, and the early Christian novel-like literature; for this see Holzberg 1995, 11-26.

30 Schlam 1992, 48-57.

31 Merkelbach 1962, 1-90; 1995, 266-303, 417-484.

32 See Shumate 1996, esp. 285-328; Bradley 1998.

33 See also Mal-Maeder 1997.

34 Hidden and profound, deeper allegorical meaning: e.g. Merkelbach 1962, 1-90; 1995, 266303, 417-484; Walsh 1970, 176-184; Griffiths 1978; Sandy 1978. No real unity and clumsy addition: e.g. Perry 1967, 242-245.

35 See now Krabbe 2003: on love, sex and food, 149-216; on love, the ass and religion, 437-471.

36 Bierl 2007, esp. 256, 260-262, 289, 306.

37 Harrison 2000, esp. 220-235.

38 Tatum 1969. 
presented as a web of different interwoven stories for the sake of entertainment. The longest inserted story is the bella fabella $(6,25,1)$, the novella of Amor and Psyche told exactly at the center of the longer narrative $(4,28-6,25) .{ }^{39}$ Although there is no real couple, and no separation is resolved in reunion and marriage in this novel, Apuleius nevertheless plays, in all respects, with the canonical norms of the genre. The ideal love novel is a tropological manifestation of love, which is constituted by a typical experience of absence. In the Metamorphoses, this is projected onto a spatial axis as a series of terrible dangers and syntagmatically transferred onto episodes of robbery, victimization, violence, death, shipwreck and fire. The emptiness, the yearning for the absent person, is thus externalized and unfolds in space. ${ }^{40}$ In contrast to the 'ideal' motifs, the narrative begins with a journey, and with an emphasis on the miraculous and magic; curiosity makes the protagonist anxious to experience wonders in Thessaly, the country of witches par excellence. The journey of adventures with attacks by robbers does not extend over the oikoumene, ${ }^{41}$ but is restricted to a small circuit between Corinth and Thessaly. The usual trip over the sea, in combination with shipwrecks and amorous misadventures, violence and apparent deaths, are all missing. In Apuleius, the dream-like wanderings resemble more an inner nightmare once Lucius has been transformed into the form of an ass. In this disguise, the young man becomes a witness of the corrupted morals of humanity. He is beaten, maltreated by robbers and his owners alike, and he observes human sexual perversion firsthand. At the end, there is no anticipated reunion. Instead, we hear about an initiation into the mysteries of Isis and Osiris in Cenchreae and Rome. The longing for sex and magic is projected onto a desire for a mystic union with a goddess and religious mysteries. ${ }^{42}$ The perspective is often satirical, the text often looks like a distanced comment on the world, and the identity of the author somehow merges with that of the protagonist.

Apart from the differences, however, we also have here many things in common with the ideal love novel. Apuleius, too, deals with the important biographical threshold of puberty which was ritually acted out in ancient Greece as a special turning point in life. ${ }^{43}$ The fictional text mirrors exactly this liminal experience and the sexual situation of a 'Betwixt and Between'. Suppressed fears

39 See e.g. Binder and Merkelbach 1968; Neumann 1979; Mantero 1973; Fehling 1977; Schlam 1993; Dowden 1998.

40 See Bierl 2006.

41 For robbers, love, folklore and initiation, see Alimonti 1986.

42 Bierl 2010.

43 See Dowden 1999; Lalanne 2006; Bierl 2007. 
and pathe are acted out in a kind of dream sequence on the level of a fairy-tale folk structure. ${ }^{44}$

In the Metamorphoses we find many of the features we have spoken about above. The hero Lucius is a young man on the threshold of adulthood. He is shy, almost girlish (de ista corporis speciosa habitudine deque hac virginali prorsus verecundia 1,23,3; see 2,2,7-9), but with an interest in miracles and magic. The latter plays a decisive role. Magic is the link to religion, to Isis and her mysteries in Book 11, as well as to love and sex, and, last but not least, to metamorphosis, which is foregrounded already in the title. Every detail is subordinated to love. The witches are lewd and voluptuous females who yearn for young men. For their charms and incantations they need magical materials, particularly fingernails, body parts, hair from their victims or from other male persons, even from corpses. They try to cast sexual spells on young men with their love enchantments (agogai). In real life, such practices were accomplished by males in order to win over and bind women. In literature, this relationship is proverbially reversed. ${ }^{45}$ Isis is the divine mistress of all magic. Beyond that, she constantly creates connections on all levels, in language and ritual. Magic and mysteries presuppose a special closeness to the gods, and their practitioners have very direct contact with the divine. ${ }^{46}$ We can see already how the twist in Book 11 has a thematic link. Moreover, magic itself has to do with metamorphosis - the lewd Pamphile changes shape into a bird in order to reach her lovers. Changes from humans into animals occur repeatedly. Transformation and manipulation of forms is an integral element of the primarily miraculous oral folktale, and conforms to the norms of the paramithia. ${ }^{47}$ In these tales, the metaphors are movers and shifters, the borders between every classification are fluid - between hero and villain, good and evil, man, animal and plant. Such continuous oscillation moves the web of the narrative by means of metaphors and metonymies from one episode to the next. Metamorphosis itself can also be understood as an image of the fundamental transition from adolescent to adult. The folktale of the ass transformed in literature acts out the most critical phase in the life of every man. ${ }^{48}$ The crisis of adolescence in the experience of girls is also reflected and debated, through the

44 For the dream-like element in Apul. Met., see Winkler 1985, 9; Franz 1980, 13, 60; in Xen. Eph. and in the novel in general, Bierl 2006, esp. 82-93; 2007, 245. For Apul. Met., see e.g. Annequin 1996; Hunink 2006.

45 Graf 1997, 175-204.

46 Graf 1997, 96-117. On magic and love, see Schlam 1992, 67-81.

47 For metamorphosis in modern Greek tales, see Alexiou 2002, 249-253.

48 See e.g. Mantero 1973; Schlam 1993 (Fehling 1977 is exaggerated), and in general Alexiou 2002. 
medium of the ass: within the texture of the narrative, we observe this experience particularly in Charite's drama, which is again refracted in the tale of Cupid and Psyche. The interpenetration of stories, themes and images in a wonderful act of weaving and sewing together of tales (varias fabulas conseram 1,1,1) is held together by the common theme of initiation, by the treatment of this fundamental crisis of liminality. ${ }^{49}$ Sex, magic and metamorphosis serve as image and text generators.

Strangely enough, hardly anybody has really seen this. ${ }^{50}$ This might be due to the apparent disjunction between Books 1-10 and Book 11, as well as to the distorting parodic, satirical, and sometimes slightly moralistic perspective. I want to stress the aspect of narrative texture in the Golden Ass and in all similar folktales. By listening to and reading such mythic paramithia, which move between the various possible categories, we find a certain consolation. The telling is in itself a sort of ritual act of staging, confronting and dealing with this crisis. It reminds people of their own liminal adolescence. The para-mithi provides consolation (paramythía) (solaretur 4,24,2) and, through images, themes and symbols, succeeds in deferring the opposites of true and fictitious/miraculous, written and oral. ${ }^{51}$

In this novel everything is sexualized. ${ }^{52}$ Twisters and shifters move the narration along the trajectory in a permanent interweaving process. By performative strategies of involving, embracing and including the listener and reader, the ritual effect is enhanced. At the same time, the perspective is sometimes inverted by comic upside-down techniques. The central metamorphosis of the hero into an ass has to be understood primarily in sexual terms. The ass is a phallic animal, ${ }^{53}$ and thus the adolescent man is 'reduced' to the consciousness of his phallus, and acts out his hypertrophied sexuality through this image. The focus of the narration

49 See Papaioannou 1998.

50 A slight exception is Dowden 1982, 342 (centering on puberty initiation in Cupid and Psyche, but in allegorical terms). Some hints of an application of the initiation paradigm can be found in the interpretation of the fable of Cupid and Psyche by non-literary scholars, particularly by representativs of depth psychology and folklore analysis, esp. à la Propp; in most cases these approaches are idiosyncratic, origin-centered, archetypical and too narrowly focussed. See Neumann 1979; Hoevels 1979, 230-286; Franz 1980, esp. 84 ('typisches Stadium eines verzögerten Pubertätsüberganges'). See also Alimonti 1986. From a broader, holistic perspective, Alexiou 2002; Neumann 2010. For a view on the sexually based motifs, see Puccini-Delbey 2003 (but with an allegorical, moralistic and philosophical twist).

51 See Alexiou 2002, 152-155.

52 Thiel 1971, 203-204; Schlam 1992, 67-81; Puccini-Delbey 2003, 15-160.

53 Winkler 1985, 174. For a phallic interpretation and a psychological view on masculinity ('male fear of being debased into the penis' 118), see Doody 1996, 117-121. 
makes this evident. Lucius is transformed into his sexual organ and witnesses or participates in many sexual episodes. Initially, he only looks on as human beings copulate, but then, he becomes increasingly involved himself in sexual acts. He is accused of sexually harassing women, he tries to kiss and caress Charite, then he is threatened with castration, and finally he virtually reverts to his human identity - he has always remained a man behind the asinine disguise - and has intercourse with a lady, whereupon he is scheduled to perform again in public with a woman criminal in the theater. Yet, like many of Apuleius's symbols and images, the donkey is also ambiguous and polyvalent. As many scholars have pointed out, the ass is also the symbol of Seth, the very enemy of Isis - thus, the retroactive and allegorical interpretation of Mithras $(11,15,4-5)$ would be symbolically confirmed. ${ }^{54}$ At the same time, the ass often stands for inversion, for comic distortion, in particular in the realm of Dionysus, for stupidity and stubbornness.

\section{Apuleius' Golden Ass as a Test Case: A Bio-Ritual Close Reading}

Let us look more closely at the plot of the Golden Ass, taking a bio-ritual approach. ${ }^{55}$ We have seen that the story of Lucius is constructed on the model of the boy's tragedy. In the time remaining to me now, I can only focus on the double inlay-story, the girl's tragedy as reflected by Charite and Psyche. Situated at the center of the narrative, this story reflects the central theme in a complementary perspective.

After being warned not to engage in magic and sex, Lucius indulges in both he enjoys Photis and is transformed into an ass by the application of the wrong magical substance. He immediately falls into the hands of brigands - usually a metaphor for others' sexual appetite for the heroine. The ass is maltreated by them, he has to carry their loot and is taken to the robbers' nest high in the mountains. A drunken old woman serves them there. After the tragic deaths of three robbers is reported, other members of the gang return with a beautiful kidnapped victim $(4,23)$, Charite, a virgin abducted just before her wedding, torn from the gremium of her mother $(4,26)$. The girl is attractive - even for an ass (puellam mehercules et asino tali concupiscendam 4,23,3). The story reflects the crisis of the marriage. Charite is desperate and the old woman undertakes to

54 Winkler 1985, 306-315; Münstermann 1995, 36-37, 50-56.

55 See Neumann 2007. 
console her (4,24,1-2). In a dream, the girl relives her abduction from the wedding feast and sees her young husband killed by a robber $(4,27)$. Now the anus really wants to console and distract her with a charming fairy tale $(4,27,8)$, the tale of Cupid and Psyche (4,28-6,24).

This inserted tale told at the second remove is a variation on and an analogous account of another girl's tragedy. ${ }^{56}$ It is a 'novel within the novel' and again tells the story of a death-wedding (funereus thalamus 4,33,1). ${ }^{57}$ The youngest of three daughters is so beautiful that she is worshipped as Venus. Her beauty, the quintessential value and precondition for marriage of young girls, is problematized. Due to her excess of beauty, people assimilate her to the goddess of beauty and love. In the manner typical of novels, the real Venus is outraged and asks Cupid to ensure that the girl be seized by passion for the ugliest and most degrading man $(4,31,3)$. All the men are eager to marry her, but no one dares to propose marriage because of her loveliness. In this unfortunate situation, her father consults the Milesian oracle of Apollo. The oracle says that she should be placed on a cliff and will marry a terrifying monster (4,33,1-2). Her parents comply with the oracle and she heroically accepts her destiny $(4,34,3-6)$. On the cliff, no monster appears, but a gentle West wind carries her down to a blossoming valley. Every detail engages and plays with the psychological crisis of the girl at the liminal declivity of the wedding. Death and marriage are interrelated in ritual expressions. This cluster of images is transferred into the dense web of a story put in motion by shifters of metaphors and metonymies. She wakes up in a beautiful palace and is surrounded by voices which provide her with every comfort (5,1-3). At night, she hears a sweet murmur - she becomes afraid for her virginity and experiences terror (virginitati suae pro tanta solitudine metuens et pavet et horrescit et quovis malo plus timet quod ignorat 5,4,2). Yet, the mysterious husband (ignobilis maritus 5,4,3) comes, slips into her bed and takes her as his wife. It is rape, but the voices console her for her lost virginity. She becomes accustomed to the strange male who returns to her every night, and she feels pleasure $(5,4,5)$. The first sexual encounter is associated with danger, risk and violence. The girl oscillates in her feelings between horror and attraction. Marriage also means separation from her family, which she misses. She asks her unknown husband to be allowed to see her sisters; at first he refuses, but then he allows her to receive them, on condition that she does not give in to their pressure to discover his identity. The sisters come to visit and become jealous, and when

56 See e.g. Binder and Merkelbach 1968; Neumann 1979; Mantero 1973; Fehling 1977; Schlam 1992, 82-98; 1993; Dowden 1982; 1998.

57 For the interpenetration of the motifs of death and marriage, see Alexiou 1974; Seaford 1987. 
they ask her about her husband, she describes him as a handsome young huntsman with downy cheeks $(5,8,4)$ - the typical description of the ephebe on the verge to adulthood. The unseen bridegroom warns Psyche again and tells her about her pregnancy with a divine child. It is a secret she should keep to herself $(5,11,5-6)$. The girl is happy about the consolation of a divine offspring and counts the days and months $(5,12,1-2)$. She is proud and wonders about the biological miracle of her metamorphosis into a mother. Psyche asks herself how her womb could swell out so after a brief 'pricking' (de brevi punctulo 5,12,2). Amor repeats his warning. The sisters come again, and this time she tells them that her lover is an already grey merchant $(5,15,4)$. The sisters lie to her that perhaps a huge serpent comes to sleep with her, and they remind her of the monster the Pythic oracle had mentioned; after the birth of the child, they say, she will be devoured $(5,17,2-18,3)$. The young husband is turned into a dragon by means of such speculations. The pricking penetration might come from a serpent. She is again horrified $(5,18,4)$. Does she really sleep with a monster? The sisters trick her into the fateful plan to hide a knife and an oil-lamp (5,20,1-2): while he is asleep after their nightly intercourse, she should light the lamp and cut off the head of the dragon. They will then help her to find a human husband (5,20,3-6). Torn by a storm of mixed feelings, she both hates and loves her mysterious partner $(5,21,3-4)$. Yet, she decides to uncover the secret and look at his face. Then she sees that the alleged monster is really Cupid, and she gazes at his face and his splendid body $(5,22)$. She sees his bow and arrows - metaphors of the sexual organ, and incautiously pricks her skin with one - another symbolic penetration. Now she irresistably falls in love with him $(5,23,1-3)$. Bending over him, she lets fall a drop of the burning oil. He wakes up and prepares to leave her, she grabs his leg and flies with him over the clouds, but falls to earth $(5,24,1)$. Amor is injured and burnt - love burns! He takes deadly revenge on the sisters. Venus, informed about everything, is furious with both of the lovers $(5,28,7-5,30)$.

All of these events rework the ambivalence of feelings of the liminal phase of puberty, the crisis of marriage and defloration, the sentiment of loss and desperation, love and the forging of a new bond, the feeling of not knowing enough about the identity of the partner, the horror and the attraction. And this 'crisis' is also reflected on the side of family - the sisters, and the mother. The sisters are potential rivals and could endanger the bond of marriage by infidelity. The mother - Venus - has to pardon her son.

Psyche now searches for her lost lover in vain. Finally, she surrenders to Venus, who sets her almost impossible tasks. The final task is to go to the Underworld to get Proserpina's box, which she succeeds in doing. Out of curiosity, she opens it and falls into a deadly sleep $(6,21,1-2)$. Amor comes and rescues her and is finally allowed to marry her. 
Before her marriage, Psyche undergoes trials, confronts death, and accepts the consequences of beauty. Marriage is death - she has experienced this from the beginning. In a self-referential loop the story acts out the cultural images and psychological strains associated with marriage. Marriage and sex are linked with secrets. As soon as the girl breaks the taboo of sexuality, she 'dies', falls asleep and accepts her new role as wife and mother. Curiosity is a vice, but it is also necessary in order to cross thresholds in a rite de passage. On the wedding night, the Horae scatter roses over everything, the symbol of sex and love $(6,24,3)$. Their daughter is Joy, Voluptas, a metonymy of Charite herself, Charm.

This long inlay narrative weaves together all the motifs of the crisis of puberty initiation and mirrors the framing story of Charite and Tlepolemus. Psyche is not necessarily just an allegory of the soul reascending to heaven or an educated meditation on the Platonic soul, ${ }^{58}$ but rather a fairy tale reworking the psychological tribulations of girls at the transitional state of 'Betwixt and Between', the soul being exhaled (see 2,17,4) and fused with the lover on their first night of love.

The ass listens to the story - like the reader, he is fascinated and drawn into the sphere of love. Being himself threatened with death by being thrown from a cliff, he decides to flee. The captive girl jumps on his back. The ass loves her at first sight, and with the pretence of scratching his back, he kisses the tender feet of the girl $(6,28,2)$. The phallic animal loves again, while the beautiful girl, in the same manner as Photis $(2,17,4)$, rides on him. The girl promises to caress and adorn the ass's body, including his tail $(6,28,5)$. Is the faithful and virtuous girl about to fall prey to the phallic animal? Or is it a new abduction from the altar? As a result of indecision at a crossroad - a symbol of sexual encounter and of a moralistic decision against it - the pair is recaptured, because the girl does not go where the lewd ass would like $(6,29,6-7)$. A dire fate is planned for them: the ass is to be killed and disembowled, the naked girl will be sewn up in the carcass, and they will be exposed on a high mountain cliff $(6,31,5-32,3)$. This is a gruesome union, a fantastic sexual interpenetration of the naked female and male bodies, an encounter with death with the heat of sun leading quickly to putresence and fetor. Furthermore, dogs and vultures will tear at the belly and the girl enclosed within it. This is another image of the sexual violence of others against the new pair. Corporeal images take over and scenes of sexual atrocities and inversions are woven into the tale. Later, he looks at his belly and imagines himself already 'pregnant' with the girl $(7,4,1)$, as Psyche had contemplated her belly. This terrible plan is deferred by a stranger who claims to be the famous robber Haemus, also with downy cheeks $(7,5,2)$, i.e. the young man on the threshold to adulthood.

58 Merkelbach 1962, 1-90; Münstermann 1995; Dowden 1998. 
Haemus, the supposed noble brigand, is told of the girl's attempted escape on the back of the ass, but he advises the robbers to execute their vengeance instead by selling her to a brothel. Heroines sold as prostitutes are a common feature of the novel. This motif expresses the depths of female infidelity and sexual excess. In the perspective of the play-within-a-play, the girl becomes quite happy, so that to the ass, the entire female sex seems to be worth reprimanding $(7,10,3)$, because it is as if she has only pretended to be the puella casta.

However, Haemus turns out to be Tlepolemus, drugs the robbers, rescues the girl and puts her back on the ass (virginem asino triumphantem 7,13,2). The couple is married, but the catastrophe materializes which the girl has dreamt about previously. The ass is again mistreated, this time by the herdsman's wife and by a cruel boy who uses him to collect wood. The boy tortures him with thorns and fire, metaphors of love. Interestingly, he also claims, apparently unreasonably, that Lucius would sexually assault any girl or boy $(7,21)$. Although this scenario of sexual harassment is fabricated, the claim nevertheless has some truth in it. Apuleius uses the blunt language of sexual attack on the body. We have already witnessed the ass being sexually aroused by Charite, and later on, he will indeed have intercourse with a rich woman in Corinth. Since he is a man - an adolescent - behind the mask, he naturally desires women; his mind is reduced to phallic behavior and sex. The later course of events is ironically encapsulated and anticipated in the 'false' accusation. The boy wants to incite the other workers to agree on sacrificing the ass $(7,22,1)$, but one of them suggests that it might be better just to castrate the lascivious animal. Exsectis genitalibus $(7,23,2)$ - he would not sexually assault women any more; even wild stallions are tamed by such a procedure. The man goes to get his instruments $(7,23,4)$, while the ass Lucius considers this a terrible punishment and laments that with the removal of his male organ he would die completely (in novissima parte corporis totum me periturum deflebam $7,24,1$ ). We realize again that in his estimation, his identity lies, in effect, precisely in his phallus.

At this point, a slave arrives and announces that Tlepolemus and Charite are dead. Thrasyllus, a 'brave' man, killed Tlepolemus on a boar hunt, a typical motif of initiation and ephebeia. ${ }^{59}$ The false friend hamstrung the horse carrying Tlepolemus - the horse is the metaphor for virility - he tried to protect his crura and also his male parts - $(8,5,10)$, but Thrasyllus struck his lance into his thigh; this is normally done by the boar. ${ }^{60}$ Tlepolemus, the man 'who is good in suffering war' ironically failed in his trial of initiation, in this case, after the wedding!

59 For a whole set of initiation motifs, see Bierl 2007, 274-276.

60 For an interpretation in terms of Isis, see Merkelbach 1962, 72-79. 
Thrasyllus pays court to the still grieving widow, again an attack on fidelity and marriage. He persists, and, after her husband has appeared to her in a dream, she fabricates a plot, letting in the evil man for a secret wedding. He should come into her darkened bedroom - which we may compare to the dark room of Psyche. For Thrasyllus, it becomes a scaena feralium nuptiarum $(8,11,1)$ - an expression we also know from Psyche. Death at a wedding is an awful threat. Charite punishes him with the Oedipal revenge of hacking out his eyes $(8,12,2-13,1)$.

In recent decades, some critics have stressed the satiric and comic-parodic side even of Book 11. Indeed, the Golden Ass is not so much a triumph of religion; rather, from the perspective of an active young man full of desire for mirabilia, magic and sex, this ending is somehow ironic and bitter. ${ }^{61}$ Even after his retransformation into human form, he makes an ass of himself, being duped into religious dependence by still clinging to a dominant female figure, Isis, the goddess of magic and love. When we compare this with the ps.-Lucianian Onos, the probable epitome of a popular Greek novel and model for the Golden Ass, we recognize Apuleius' innovation. The Onos merely reflects the fairy-tale level of basic human instincts: Lucius comes back to the rich lady and wants to repeat his sexual experience with her, but when she sees the small size of his penis, she loses interest in him and expels him. Under the influence of the Second Sophistic, which tended to an ostentatious display of learning, Apuleius wants to enrich this plot line with religious and philosophical meaning. However, behind this allegorizing coloring, we still detect the continuous web of motifs woven into a plot which has its roots in ordinary life and folk tale. It deals less with initiation into mystery cults than with pubescent initiation into adulthood. Within its surface structure, the Golden Ass debates, reworks and acts out the crisis of the liminal phase of adolescence. The texture of the plot interweaves images of the boy's tragedy and the maiden's tragedy and draws heavily on metaphors and metonymies which are all linked to this fundamental crisis of puberty. This interpretation, however, does not overlook the fact that Apuleius, as a religious man and philosophus Platonicus, enriches this bio-ritual plot with all sorts of allegorizing material. He applies such a polyvalent perspective in order to appropriate a higher meaning which he simultaneously deconstructs. He plays with and displays educated discourses by projecting the telos of initiation and of the sight of the eternal forms onto the substrata of the plot. These ideal and exalted goals can be reached only after a difficult ascent through a hierarchy of grades. And yet, the playful auctor pokes fun at an actor striving hard to reach a permanently deferred ideal of Love.

61 See Mal-Maeder 1997; Harrison 2000, 210-259. 


\section{Bibliography}

Alexiou, M. 1974. The Ritual Lament in Greek Tradition, revised by D. Yatromanolakis and P. Roilos, Lanham et al.: Rowman \& Littlefield $2002^{2}$ (Cambridge 1974').

Alexiou, M. 2002. After Antiquity. Greek Language, Myth, and Metaphor, Ithaca, NY and London: Cornell University Press.

Alimonti, T. 1986. 'Letteratura e folclore: I latrones di Apuleio e i briganti di Propp', CCC 7, 59-76. Annequin, J. 1996. 'Rêve, roman, initiation dans les Métamorphoses d'Apulée', DHA 22, 133-201.

Beck, R. 1982. 'Soteriology, the Mysteries, and the Ancient Novel: lamblichus Babyloniaca as a Test-Case', in: U. Bianchi and M. J. Vermaseren (eds.), La soteriologia dei culti orientali nell'impero romano, Leiden: Brill. 527-537.

Bierl, A. 2001. Der Chor in der Alten Komödie. Ritual und Performativität (unter besonderer Berücksichtigung von Aristophanes' Thesmophoriazusen und der Phalloslieder fr. 851 PMG), Munich and Leipzig: Saur.

Bierl, A. 2002. 'Charitons Kallirhoe im Lichte von Sapphos Priamelgedicht (Fr. 16 Voigt). Liebe und Intertextualität im griechischen Roman', Poetica 34, 1-27.

Bierl, A. 2006. 'Räume im Anderen und der griechische Liebesroman des Xenophon von Ephesos. Träume?', in: A. Loprieno (ed.), Mensch und Raum von der Antike bis zur Gegenwart, Munich and Leipzig: Saur. 71-103.

Bierl, A. 2007. 'Mysterien der Liebe und die Initiation Jugendlicher. Literatur und Religion im griechischen Roman', in: A. Bierl, R. Lämmle and K. Wesselmann (eds.), Literatur und Religion II. Wege zu einer mythisch-rituellen Poetik bei den Griechen, Berlin and New York: de Gruyter. 239-334.

Bierl, A. 2010. 'Antike Mysterien - ein Weg zur Vollkommenheit und die literarische Verarbeitung in Apuleius' Metamorphosen', in: A. Assmann and J. Assmann (eds.), Vollkommenheit (Archäologie der Literarischen Kommunikation X), Munich: Wilhelm Fink Verlag. 83-106.

Binder, G. and R. Merkelbach (eds.) 1968. Amor und Psyche, Darmstadt: Wissenschaftliche Buchgesellschaft.

Bradley, K. 1998. 'Contending with Conversion: Reflections on the Reformation of Lucius the Ass', Phoenix 52, 315-334.

Burkert, W. 1987. Ancient Mystery Cults, Cambridge, MA and London: Harvard Press.

Burkert, W. 1996. Creation of the Sacred. Tracks of Biology in Early Religions, Cambridge, MA and London: Harvard University Press.

Doody, M. A. 1996. The True Story of the Novel, New Brunswick: Rutgers University Press.

Dowden, K. 1982. 'Psyche on the Rock', Latomus 41, 336-352.

Dowden, K. 1998. 'Cupid \& Psyche. A Question of the Vision of Apuleius', in: M. Zimmerman, V. Hunink et al. (eds.), Aspects of Apuleius' Golden Ass, II, Groningen: Egbert Forsten. 1-22.

Dowden, K. 1999. 'Fluctuating Meanings: 'Passage Rites' in Ritual, Myth, Odyssey, and the Greek Romance', in: M. W. Padilla (ed.), Rites of Passage in Ancient Greece. Literature, Religion, Society, Lewisburg: Bucknell University Press. 221-243.

Dowden, K. 2005. 'Greek Novel and the Ritual of Life: An Exercise in Taxonomy', in: S. Harrison, M. Paschalis and S. Frangoulidis (eds.), Metaphor and the Ancient Novel (Ancient Narrative, Suppl. 4), Groningen: Barkhuis \& Groningen University Library. 23-35.

Fehling, D. 1977. Amor und Psyche. Die Schöpfung des Apuleius und ihre Einwirkung aufdas Märchen, eine Kritik der romantischen Märchentheorie, Mainz: Franz Steiner Verlag. 
Fernandez, J. W. 1977. 'The Performance of Ritual Metaphors', in: J. D. Sapir and J. C. Crocker (eds.), The Social Use of Metaphor. Essays on the Anthropology of Rhetoric, Philadelphia: University of Pennsylvania Press. 100-131.

Fernandez, J. W. (ed.) 1986. Persuasions and Performances. The Play of Tropes in Culture, Bloomington: Indiana University Press.

Fernandez, J. W. (ed.) 1991. Beyond Metaphor. The Theory of Tropes in Anthropology, Stanford: Stanford University Press.

Franz, M.-L. von 1980. Die Erlösung des Weiblichen im Manne. Der goldene Esel von Apuleius in tiefenpsychologischer Sicht, Frankfurt a. M.: Insel Verlag.

Gennep, A. van 1960. The Rites of Passage, Chicago: The University of Chicago Press (French orig. Paris 1909).

Graf, F. 1997. Magic in the Ancient World, translated by F. Philip, Cambridge, MA and London: Harvard University Press.

Greenblatt, S. 1988. Shakespearean Negotiations. The Circulation of Social Energy in Renaissance England, Oxford: Clarendon Press.

Griffiths, J. G. 1978. 'Isis in the Metamorphoses of Apuleius', in: B. L. Hijmans Jr. and R. T. van der Paardt (eds.), Aspects of Apuleius' Golden Ass, Groningen: Bouma’s Boekhuis. 141-166.

Habinek, T. N. 1990. 'Lucius' Rite of Passage', MD 25, 49-69.

Harrison, S. J. 2000. Apuleius. A Latin Sophist, Oxford: Oxford University Press.

Harrison, S. 2007. 'Parallel Cults? Religion and Narrative in Apuleius' Metamorphoses and Some Greek Novels', in: M. Paschalis, S. Frangoulidis, S. Harrison and M. Zimmerman (eds.), The Greek and the Roman Novel. Parallel Readings (Ancient Narrative, Suppl. 8), Groningen: Barkhuis \& Groningen University Library 2007. 204-218.

Hoevels, F. E. 1979. Märchen und Magie in den Metamorphosen des Apuleius von Madaura, Amsterdam: Rodopi.

Holzberg, N. 1995. The Ancient Novel. An Introduction, translated by C. Jackson-Holzberg, London and New York: Routledge.

Hunink, V. 2006. 'Dreams in Apuleius' Metamorphoses', in: A. P. M. H. Lardinois, M. G. M. van der Poel and V. J. C. Hunink (eds.), Land of Dreams. Greek and Latin Studies in Honour of A. H. M. Kessels, Leiden and Boston: Brill. 18-31.

Kerényi, K. 1927. Die griechisch-orientalische Romanliteratur in religionsgeschichtlicher Beleuchtung, Darmstadt: Wissenschaftliche Buchgesellschaft $1973^{3}$ (Tübingen: Mohr 1927¹).

Krabbe, J. K. 2003. Lusus iste: Apuleius' Metamorphoses, Dallas et al.: University Press of America.

Lalanne, S. 2006. Une éducation grecque. Rites de passage et construction des genres dans le roman grec ancien, Paris: La Découverte.

Mal-Maeder, D. van 1997. 'Lector, intende: laetaberis. The Enigma of the Last Book of Apuleius' Metamorphoses', GCN 8, 87-118.

Mantero, T. 1973. Amore e Psiche. Struttura di una 'fabia di magia', Genoa: Università di Genova.

Merkelbach, R. 1962. Roman und Mysterium in der Antike, Munich and Berlin: Beck.

Merkelbach, R. 1988. Die Hirten des Dionysos. Die Dionysos-Mysterien der römischen Kaiserzeit und der bukolische Roman des Longus, Stuttgart: Teubner.

Merkelbach, R. 1995. Isis Regina - Zeus Sarapis. Die griechisch-ägyptische Religion nach den Quellen dargestellt, Munich and Leipzig: Saur $2001^{2}$ (Stuttgart and Leipzig: Teubner 19951).

Morgan, J. R. 1996. 'Erotika Mathemata: Greek Romance as Sentimental Education', in:

A. H. Sommerstein and C. Atherton (eds.), Education in Greek Fiction, Bari: Levante editori. 163-189. 
Münstermann, H. 1995. Apuleius. Metamorphosen literarischer Vorlagen. Untersuchung dreier Episoden des Romans unter Berücksichtigung der Philosophie und Theologie des Apuleius, Stuttgart and Leipzig: Teubner.

Neumann, E. 1979. Amor and Psyche. Deutung eines Märchens, Olten and Freiburg i. Br.: WalterVerlag $\left(1971^{1}\right)$.

Neumann, G. 2000. 'Begriff und Funktion des Rituals im Feld der Literaturwissenschaft', in: G. Neumann and S. Weigel (eds.), Lesbarkeit der Kultur. Literaturwissenschaften zwischen Kulturtechnik und Ethnographie, Munich: Wilhelm Fink Verlag. 19-52.

Neumann, M. 2007. ‘Die fünf Ströme des Erzählens. Zur Ökologie des Narrativen', in: K. Eibl, K. Mellmann and R. Zymner (eds.), Im Rücken der Kulturen, Paderborn: Mentis Verlag. 373-394.

Neumann, M. 2010. 'Danae, Rapunzel und ihre Schwestern. Zu Walter Burkerts Konzept der Mädchentragödie', in: A. Bierl and W. Braungart (eds.), Gewalt und Opfer. Im Dialog mit Walter Burkert, Berlin and New York: de Gruyter. 317-341.

Papaioannou, S. 1998. 'Charite's Rape, Psyche on the Rock and the Parallel Function of Marriage in Apuleius' Metamorphoses', Mnemosyne 51, 302-324.

Perry, B. E. 1967. The Ancient Romances. A Literary-Historical Account of their Origins, Berkeley and Los Angeles: University of California Press.

Puccini-Delbey, G. 2003. Amour et désir dans les Métamorphoses d'Apulée, Brussels: Éditions Latomus.

Reardon, B. P. 1991. The Form of Greek Romance, Princeton: Princeton University Press.

Sandy G. N. 1978. ‘Book 11: Ballast or Anchor?', in: B. L. Hijmans Jr. and R. T. van der Paardt (eds.), Aspects of Apuleius' Golden Ass, Groningen: Bouma's Boekhuis. 123-140.

Schlam, C. C. 1992. The Metamorphoses of Apuleius. On Making an Ass of Oneself, Chapel Hill: The University of North Carolina Press.

Schlam, C. C. 1993. 'Cupid and Psyche: Folktale and Literary Narrative', GCN 5, 63-73.

Seaford, R. 1987. 'The Tragic Wedding', JHS 107, 106-130.

Shumate, N. 1996. Crisis and Conversion in Apuleius' Metamorphoses, Ann Arbor: The University of Michigan Press.

Tatum, J. 1969. 'The Tales in Apuleius' Metamorphoses', TAPhA 100, 487-527 (repr. in: S. J. Harrison (ed.), Oxford Readings in the Roman Novel, Oxford: Oxford University Press 1999, 157-194).

Thiel, H. van 1971. Der Eselsroman, I. Untersuchungen, Munich: Beck.

Turner, V. W. 1967. The Forest of Symbols. Aspects of Ndembu Ritual, Ithaca: Cornell University Press.

Versnel, H. S. 1993: Inconsistencies in Greek and Roman Religion, II. Transition and Reversal in Myth and Ritual, Leiden et al.: Brill.

Walsh, P. G. 1970. The Roman Novel. The Satyricon of Petronius and the Metamorphoses of Apuleius, Cambridge: Cambridge University Press.

Whitmarsh, T. 1999. 'The Writes of Passage. Cultural Initiation in Heliodorus' Aethiopica', in: R. Miles (ed.), Constructing Identities in Late Antiquity, London and New York: Routledge. 16-40.

Winkler, J. J. 1982. 'The Mendacity of Kalasiris and the Narrative Strategy of Heliodoros' Aithiopika', YCIS 27, 93-158.

Winkler, J. J. 1985. Auctor \& Actor. A Narratological Reading of Apuleius's Golden Ass, Berkeley, Los Angeles and Oxford: University of California Press.

Zeitlin, F. I. 2008. 'Religion', in: T. Whitmarsh (ed.), The Cambridge Companion to the Greek and Roman Novel, Cambridge: Cambridge University Press. 91-108. 